\title{
Identification of proteins involved in the pancreatic exocrine by exogenous ghrelin administration in Sprague-Dawley rats
}

Kyung-Hoon Lee1, Tao Wang ${ }^{1}$, Yong-Cheng Jin², Sang-Bum Lee', Jin-Ju Oh¹, Jin-Hee Hwang ${ }^{1}$, Ji-Na Lim¹, Jae-Sung Lee ${ }^{1}$ and Hong-Gu Lee ${ }^{1 *}$

\begin{abstract}
The aims of study were to investigate the effects of intraperitoneal (i.p.) infusion of ghrelin on pancreatic a-amylase outputs and the responses of pancreatic proteins to ghrelin that may relate to the pancreatic exocrine. Six male Sprague-Dawley rats (300 g) were randomly divided into two groups, a control group $(C, n=3)$ and a treatment group $(T, 10.0 \mu \mathrm{g} / \mathrm{kg} \mathrm{BW}, \mathrm{n}=3)$. Blood samples were collected from rat caudal vein once time after one hour injection. The concentrations of plasma ghrelin, cholecystokinin (CCK) and alfa-amylase activity were evaluated by enzyme immunoassay (EIA) kit. Two-dimensional gel electrophoresis (2-DE) analysis was conducted to separate the proteins in pancreas tissue. Results showed that the i.p. infusion of ghrelin at doses of $10.0 \mu \mathrm{g} / \mathrm{kg}$ body weight (BW) increased the plasma ghrelin concentrations $(p=0.07)$ and elevated the plasma CCK level significantly $(p<0.05)$. Although there was no statistically significant, the a-amylase activity tended to increase. The proteomics analysis indicated that some pancreatic proteins with various functions were up- or down- regulated compared with control group. In conclusion, ghrelin may have role in the pancreatic exocrine, but the signaling pathway was still not clear. Therefore, much more functional studies focus on these found proteins are needed in the near future.
\end{abstract}

Keywords: Alfa-amylase activity, Cholecystokinin, Ghrelin, Pancreatic exocrine, Sprague-Dawley rats, Two-dimensional gel electrophoresis

\section{Background}

Ghrelin is a 28-amino-acid peptide isolated from the rat stomach in 1999 which is mainly produced by X/A-like cells in the oxyntic mucosa [1]. It was also found in other parts like hypothalamus, pituitary gland, lung, kidney [2-4], duodenum, ileum, colon and pancreas [5]. The ghrelin receptors (GHS-R) have been detected in many central and peripheral tissues and pancreatic $\alpha$-cells, $\beta$-cells, exocrine cells. Ghrelin shows a number of actions at the gastrointestinal tract level. It is well known as a stronger activator of growth hormone $(\mathrm{GH})$ through central nervous system (CNS) and modulation of food intake. And it also exhibits lots of other biological activities including energy expenditure, stimulation of lactotroph and corticotroph secretion,

\footnotetext{
* Correspondence: hglee66@konkuk.ac.kr

'Department of Animal Science and Technology, College of Animal Bioscience \& Technology, Konkuk University, 120 Neungdong-ro, Seoul, Gwangjin-gu 143-701, South Korea

Full list of author information is available at the end of the article
}

influence on sleep and behavior or modulation of heart rate and blood pressure ([6-9]; Assakawa et al. [10]).

Recent studies demonstrated that ghrelin could modulate exocrine secretions as well as pancreatic endocrine secretions. There were two opposite theories. First, Zhang and coworkers demonstrated that intravenous administration of ghrelin to the rats produced inhibition of enzyme secretion, and that this inhibitory effect of ghrelin on pancreatic exocrine secretion is indirect and may be exerted at the level of intrapancreatic neurons [11]. In contrast, other studies revealed that central as well as peripheral administration of ghrelin significantly increased pancreatic fluid and protein output, though the activation of vagal centers in the brainstem and stimulation of vagal efferent nerves $[12,13]$. It is generally believed that, in the intestinal phase, stimulation of pancreatic enzyme secretion depends, in the main part, on the neuronal mechanism involved in the CCK release and activation of cholinergic vago-vagal enteropancreatic reflex. However, these physiological roles of ghrelin in the 
modulation of exocrine pancreatic functions are still unclear (Gherlaldoni et al. [14]).

Therefore, this study was conducted to determine the effects of exogenous ghrelin, given intraperitoneal (i.p.) on plasma CCK level and $\alpha$-amylase output in the sprague-dawley rats. Meanwhile, the responses of pancreatic proteins to ghrelin were also analyzed using the 2-DE system.

\section{Methods}

\section{Materials}

Rat ghrelin peptide was obtained from Bachem (Bubendorf, Switzerland). Rat plasma ghrelin and CCK enzyme immunoassay kit were purchased from Phoenix Pharmaceuticals (Mountain View, CA, USA). The $\alpha$-amylase activity analyzed using an EnzyChrom ${ }^{\mathrm{Tm}}$ a-Amylase Assay Kit (ECAM-100).

\section{Animals}

Sprague-Dawley rats (300 g) (Samtaco, Osan, Korea) were used for all experiments. Animals were housed at one animal per cage on a $12 / 12 \mathrm{~h}$ light cycle (lights on at $8 \mathrm{am}$ ) and given access to food and water ad libitum. Ghrelin (0.1, $1.0,10.0 \mathrm{ug} / \mathrm{kg}$, respectively) were injected intraperitoneally in rats. One hour after injection, blood samples $(1 \mathrm{ml})$ were collected from rat caudal vein once time into heparined tube and immediately centrifuged (3,000 rpm/min, $15 \mathrm{~min})$ to obtain the plasma. Aliquots of plasma were stored at $-80^{\circ} \mathrm{C}$ till analyzed. Then rats were anaesthetized via intramuscular injection of zoletil (Vetbutal) at a dose of $15.0 \mathrm{mg} / 300 \mathrm{~g}(\mathrm{BW})$. And the rat pancreas tissues were collected. All experimental procedures were in accordance with the "Guidelines for the Care and Use of Experimental Animals of Pusan National University".

\section{Determination of plasma ghrelin, CCK concentration and a-amylase activity}

The plasma ghrelin and CCK concentration were separately determined by enzyme immunoassay kit (Phoenix Pharmaceuticals, Inc., Burlingame, CA, USA). The plasma $\alpha$-amylase activity analyzed using an EnzyChrom ${ }^{\text {mu }}$ a-Amylase Assay Kit (ECAM-100, BioAssay Systems, Hayward, CA, USA). All the operations were done followed the kit manual.

\section{Pancreas sample preparation and 2-DE analysis}

Pancreatic tissues were collected and then pulverized into powder under liquid nitrogen and stored at $-80^{\circ} \mathrm{C}$ until use. Tissues $(0.5 \mathrm{~g})$ were homogenized in $1 \mathrm{ml}$ lysis solution containing $7 \mathrm{M}$ urea, $2 \mathrm{M}$ thiourea, $4 \%$ chaps, $40 \mathrm{mM}$ Tris, $65 \mathrm{mM}$ DTT, 0.5\% IPG buffer and 1X protease inhibitor (GE Healthcare, Piscataway, New Jersey, USA). This mixture was stirred every $5 \mathrm{~min}$ for $30 \mathrm{~min}$ and then centrifuged at $14,000 \mathrm{rpm}$ for $30 \mathrm{~min}$ at $20^{\circ} \mathrm{C}$. The supernatant was then stored in aliquots at $-80^{\circ} \mathrm{C}$ until analysis.
2-DE was performed of pooling pancreatic tissue samples from three animals in each group. Briefly, protein samples were diluted into isoelectric focusing (IEF) buffer containing $6 \mathrm{M}$ urea, $2 \mathrm{M}$ thiourea, 1\% 3-((3-Cholamidopropyl) dimethylammonium)-1-propanesulfonate (CHAPS), $0.002 \%$ bromophenol blue, $0.5 \%$ phamalyte $(\mathrm{pH} 3-10 \mathrm{NL})$ and 65 $\mathrm{mM}$ dithiothreitol (DTT). Then $100 \mu \mathrm{g}$ protein smaples of control or treatment was loaded on Immobiline DryStrip gels $(\mathrm{pH}$ 3-10NL, $18 \mathrm{~cm}$, GE Healthcare) for rehydration for $12 \mathrm{~h}$ at $20^{\circ} \mathrm{C}$. The IEF procedures were performed using an IEF electrophoresis unit (GE Healthcare) following the manufacturer's protocols. The following voltage program was used after the $12 \mathrm{~h}$ rehydration: linear ramp from 500 to $1000 \mathrm{~V}$ over $2 \mathrm{~h}$, then a constant voltage of $8000 \mathrm{~V}$ for 7 $\mathrm{h}$ to give a total of $56,000 \mathrm{~V} \mathrm{~h}$. After focusing, gel strips were equilibrated in a solution containing $50 \mathrm{mM}$ Tris/HCl (pH 8.8), $6 \mathrm{M}$ urea, $2 \%$ SDS, 30\% glycerol, $0.002 \% \mathrm{w} / \mathrm{v}$ bromophenol blue and DTT for $15 \mathrm{~min}$, followed by incubation in the same solution but replacing DTT with $135 \mathrm{mM}$ iodoacetamide (IAA) for another $15 \mathrm{~min}$. After that the equilibrated strips were inserted into sodium dodecyl sulfate polyacrylamide gel electrophoresis (SDS-PAGE) gels $(18 \mathrm{~cm}, 12 \%)$. SDS-PAGE was performed using an Ettan DALT 2-D gel system (GE Healthcare). Upon completion, gels were stained using a PluseOne Silver Staining Kit (GE Healthcare). The silverstained gels were scanned using an Umax scanner (PowerLook 2100XL, UMAX Technologies, Inc., Dallas, TX, USA). Scanned gel images were processed by Proteomweaver ${ }^{\mathrm{Tm}}$ 2-D Analysis Software (Definiens AG, Munich, Germany).

\section{Statistical analysis}

Data are presented as mean \pm standard error of the mean (SEM). The group mean values were compared with an independent sample $t$-test (SPSS 14.0, Chicago, IL, USA). A $p$-value $<0.05$ was considered to be statistically significant.

\section{Results and discussion}

The i.p. infusion of ghrelin at doses of $10.0 \mu \mathrm{g} / \mathrm{kg}$ body weight $(\mathrm{BW})$ increased the plasma ghrelin concentrations $(p=0.07)$ and elevated the plasma CCK level significantly $(p<0.05)$. Although there was no statistically significant, the $\alpha$-amylase activity tended to increase (Table 1 ). These data indicated that ghrelin may have role in pancreatic exocrine secretion through the stimulation of CCK release and

Table 1 Relationship between plasma G.I. hormones and a-amylase activity

\begin{tabular}{cccc}
\hline Items & Ghrelin $(\mathbf{n g} / \mathbf{m l})$ & $\mathbf{C C K}(\mathbf{n g} / \mathbf{m l})$ & $\boldsymbol{a}$-amylase (U/L) \\
\hline Control $^{1}$ & $0.202 \pm 0.152^{2 *}$ & $5.745 \pm 2.428$ & $3791.799 \pm 208.308$ \\
Treatment $^{1}$ & $3.223 \pm 2.140$ & $11.306 \pm 3.937$ & $4210.847 \pm 262.825$ \\
\hline
\end{tabular}

${ }^{1}$ Control $=$ vehicle $/ 500$ uLSaline, Treatment $=$ Ghrelin $(10.0$ ug $/ \mathrm{kg}) / 500$ uLSaline. ${ }^{2}$ Data are mean \pm SEM and ${ }^{*}$ means significantly different, $\mathrm{p}<0.05$ (Student's paired $t$-test). 


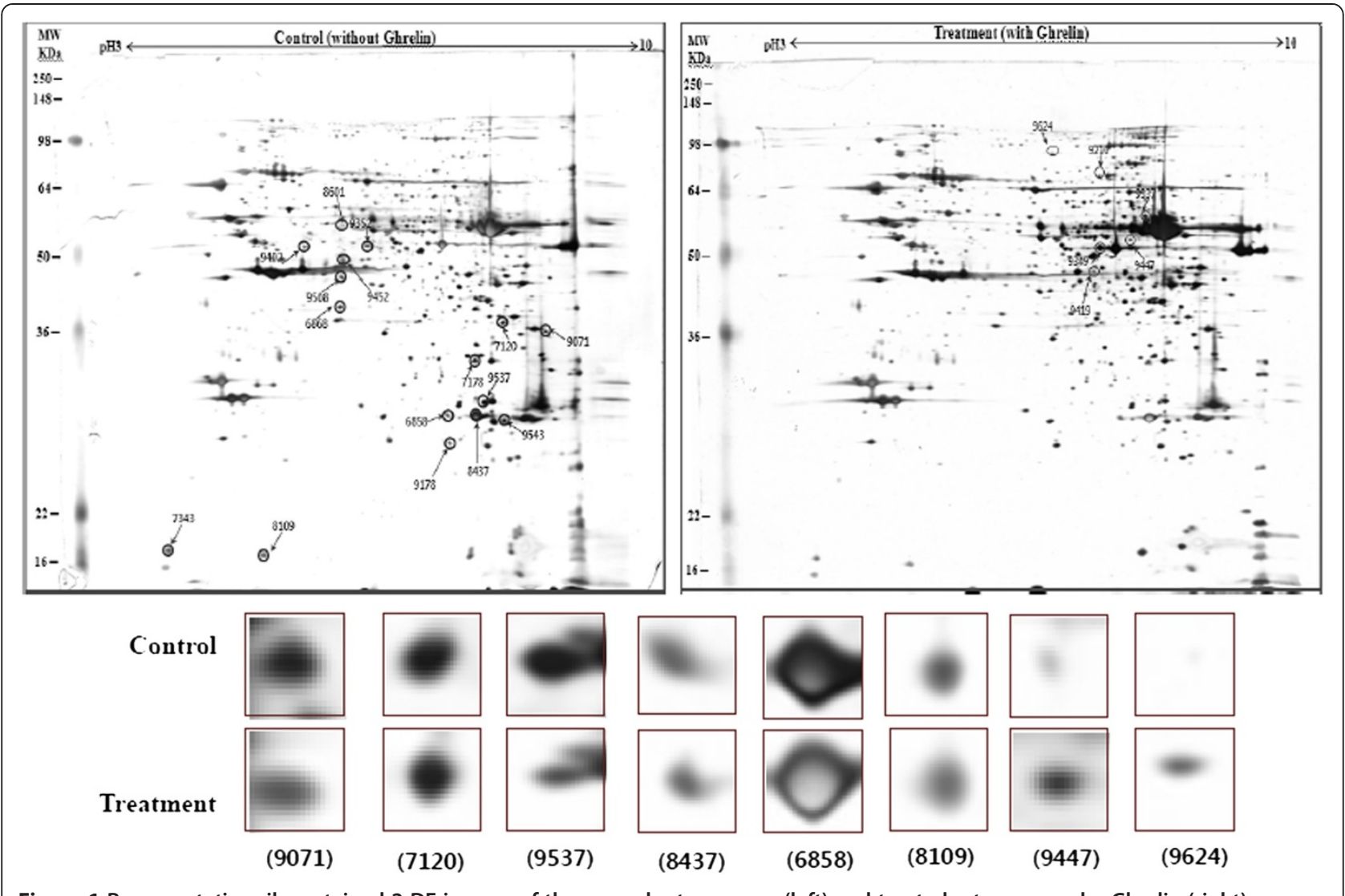

Figure 1 Representative silver-stained 2-DE images of the normal rat pancreas (left) and treated rat pancreas by Ghrelin (right).

activation of dorsal vagal nerve. CCK is one of the major gut hormones which released from duodenal mucosa I cells. It can stimulate pancreatic exocrine secretion via activation of CCK1 receptors and entero-pancreatic vago-vagal reflex [15-19]. Whether CCK plays a role in the exocrine secretion response to ghrelin is unknown.
The response of pancreatic proteins to ghrelin administration were analyzed by $2-\mathrm{DE}$ in order to get a better understanding of the mechanisms involved in the ghrelin-exocrine secretion through CCK signal. Eight spots ranging from 6 to $200 \mathrm{kDa}$ were detected differently expressed in the pancreatic protein map (Figure 1). One

Table 2 Identification of differentially altered protein spots in rat pancreas by ESI/Q-TOF MS

\begin{tabular}{|c|c|c|c|c|c|}
\hline Spot & Protein name & Peptide match & Protein score & Mass (bp) & Expression (treatment/control) \\
\hline \multicolumn{6}{|c|}{ Cell growth and proliferation } \\
\hline 8109 & Eukaryotic translation initiation factor $5 \mathrm{~A}-1$ & 295 & 98.23 & 16821.4 & Down \\
\hline \multicolumn{6}{|c|}{ Gluconeogenesis } \\
\hline 9071 & Malate dehydrogenase, mitochondrial precursor & 40 & 100.29 & 35660.8 & Down \\
\hline \multicolumn{6}{|c|}{ De nove purine biosynthesis } \\
\hline 9447 & Similar to adenylosuccinate lyase & 67 & 214.27 & 54817 & Up \\
\hline \multicolumn{6}{|c|}{ Oxidative stress } \\
\hline 6858 & PRx IV & 44 & 104.23 & 30988.1 & Down \\
\hline 7120 & Thiosulfate sulfurtransferase & 392 & 154.28 & 33385.8 & Down \\
\hline 9624 & Sarcosine dehydrogenase, mitochondrial precursor & 115 & 238.23 & 101578.9 & Only Treatment \\
\hline \multicolumn{6}{|c|}{ Others } \\
\hline 8437 & $\begin{array}{l}\text { Ubiquinol-cytochrome c reductase } \\
\text { iron-sulfur subunit, mitochondrial precursor }\end{array}$ & 55 & 100.32 & 29427.2 & Down \\
\hline 9537 & Carbonic anhydrase 3 & 297 & 148.26 & 29412.7 & Down \\
\hline
\end{tabular}


spot was up-regulated and six were down-regulated compared with control group. One spot was found only expressed in treatment group. These proteins were classified according to their functions (Table 2). Three downregulated proteins eukaryotic translation initiation factor 5A-1 (eIF5A), peroxiredoxin IV (PRx IV) and ubiquinolcytochrome c reductase (UQCR) were particular interested. eIF5A is involved in biosynthesis of pancreatic enzyme by increasing plasma CCK level [20]. And this data was different with ours. Judging by our reports, ghrelin may affect on pancreatic exocrine secretion via other factors as well as releasing CCK. Also, Yannick demonstrated that UQCR and PRx IV down-regulated biosynthesis of insulin related to diabetes [21]. Synthetically, when the effects of exogenous ghrelin, given intraperitoneal (i.p.) on pancreatic exocrine secretion, we have to consider other factor like growth hormone related to insulin synthesis as involving the CCK release and activation of cholinergic vago-vagal enteropancreatic reflex.

\section{Conclusions}

In conclusion, our result suggest a role of ghrelin on pancreatic exocrine, but the protein concerning with mechanism functional study was uncompleted. And some following functional study of proteins will be done in the near future.

\section{Competing interests}

The authors declare that they have no competing interests.

\section{Authors' contributions}

HGL conceived and designed the Experiments. KHL executed the experiment and analyzed the samples. TW revised the manuscript. All authors interpreted the data, critically revised the manuscript for important intellectual contents and approved the final version.

\section{Acknowledgments}

This research was supported by Bioindustry Technology Development Program (313020041SB010) for Ministry of Agriculture, Food and Rural Affairs, Republic of Korea.

\section{Author details}

'Department of Animal Science and Technology, College of Animal Bioscience \& Technology, Konkuk University, 120 Neungdong-ro, Seoul, Gwangjin-gu 143-701, South Korea. ${ }^{2}$ Department of Animal Science, College of Animal Science and Veterinary Medicine, Jilin University, Changchun 130062, P. R. China.

Received: 25 April 2014 Accepted: 7 May 2014

Published: 5 June 2014

\section{References}

1. Kojima M, Hasoda H, Date Y, Nakazato M, Matsou H, Kangawa K: Ghrelin is a growth-hormone-releasing acylated peptide from stomach. Nature 1999, 402:656-660.

2. Muccioli G, Tschop M, Papotti M, Deghenghi R, Heiman M, Ghigo E: Neuroendocrine and peripheral activities of ghrelin: implications in metabolism and obesity. Eur J Pharmacol 2002, 440(2-3):235-254.

3. Korbonits M, Kojima M, Kangawa K, Grossman AB: Presence of ghrelin in normal and adenomatous human pituitary. Endocrine 2001, 14:101-104.

4. Volante M, Fulcheri E, Allia E, Cerrato M, Pucci A, Papotti M: Ghrelin expression in fetal infant and adult human lung. J Histochem Cytochem 2002, 50:1013-1021.
5. Date Y, Kojima M, Hosoda H, Sawaguchi A, Mondal MS, Suganuma T, Matsukura S, Kangawa K, Nakazato M: Ghrelin, a novel growth hormone-releasing acylated peptide, is synthetized in a distinct endocrine cell type in the gastrointestinal tracts of rats and humans. Endocrinology 2000, 141:4255-4261.

6. Ghigo E, Arvat E, Giordano R, Broglio F, Gianotti L, Maccario M, Bisi G, Graziani A, Papotti M, Muccioli G, Deghenghi R, Camanni F: Biologic activities of growth hormone secretagouges in humans. Endocrine 2001, 14:87-93.

7. Tschop M, Smiley DL, Heiman ML: Ghrelin induces adiposity in rodents. Nature 2000, 407:908-913.

8. Nakazato M, Murakami N, Date Y, Kojima M, Matsuo H, Kangawa K, Matsukura S: A role for ghrelin in the central regulation of feeding. Nature 2001, 409:194-198.

9. Tolle V, Bassant MH, Zizzari P, Poindessous-Jazat F, Tomasetto C, Epelbaum J, Bluet-Pajot MT: Ultradian rhythmicity of ghrelin secretion in relation with $\mathrm{GH}$, feeding behavior, and sleep-wake patterns in rats. Endocrinology 2002, 143:1353-1361.

10. Asakawa A, Inui A, Kaga T, Yuzuriha H, Nagata T, Fujimiya M, Katsuura G, Makino S, Fujino MA, Kasuga M: A role of ghrelin in neuroendocrine and behavioral responses to stress in mice. Neuroendocrinology 2001, 74:143-147.

11. Broglio F, Prodam F, Me E, Riganti F, Lucatello B, Granata R, Benso A, Muccioli G, Ghigo E: Ghrelin: endocrine, metabolic and cardiovascular actions. J Endocrinol Invest 2005, 28(5 suppl):23-25.

12. Sato N, Kanai S, Takano S, Kurosawa M, Funakoshi A, Miyasaka K: Central administration of ghrelin stimulates pancreatic protein exocrine secretion via the vagus in conscious rats. Jpn J Physiol 2003, 53(6):443-449.

13. Li Y, Wu X, Zhao Y, Chen S, Owyang C: Ghrelin acts on the dorsal vagal complex to stimulate pancreatic protein secretion. Am J Physiol Liver Physiol 2006, 290(6):G1350-G1358.

14. Ghelardoni S, Carnicelli V, Frascarelli S, Ronca-Testoni S, Zucchi R: Ghrelin tissue distribution: comparison between gene and protein expression. J Endocrinol Invest 2006, 29(2):115-121.

15. Brzozowska I, Konturek PC, Brzozowski T, Konturek SJ, Kwiecien S, Pajdo R, Drozdowicz D, Pawlik M, Ptak A, Hahn EG: Role of prostaglandins, nitric oxide sensory nerves and gastrin in acceleration of ulcer healing by melatonin and its precursor; L-tryptophan. J Pineal Res 2002, 32:149-162.

16. Jahovic N, Sener G, Cevik H, Ersoy Y, Arbak S, Yeğen BC: Amelioration of metotrexate-induced enteritis by melatonin in rats. Cell Biochem Function 2004, 22:169-178

17. Jaworek J, Nawrot K, Konturek SJ, Leja-Szpak A, Thor P, Pawlik WW: Melatonin and its precursor; L-tryptophan: influence on pancreatic amylase secretion in vivo and in vitro. J Pineal Res 2004, 36:156-164.

18. Leja-Szpak A, Jaworek J, Nawrot-Porabka K, Palonek M, Mitis-Musioł M, Dembiński A, Konturek SJ, Pawlik WW: Modulation of pancreatic enzyme secretion by melatonin and its precursor; L-tryptophan. Role of CCK and afferent nerves. J Physiol 2004, 55:441-451.

19. Li Y, Owyang C: High affinity CCK-A receptors on the vagus nerve mediate CCK-stimulated pancreatic secretion in the rat. Am J Physiol 1997, 273:G679-G685.

20. Bragado MJ, Tashiro M, Williams JA: Regulation of the initiation of pancreatic digestive enzyme protein synthesis by cholecystokinin in rat pancreas in vivo. Gastroenterology 2000, 119(6):1731-1739.

21. Brunner Y, Schvartz D, Priego-Capote F, Couté Y, Sanchez JC: Glucotoxicity and pancreatic proteomics. J Proteomics 2009, 71(6):576-591.

doi:10.1186/2055-0391-56-6

Cite this article as: Lee et al: Identification of proteins involved in the pancreatic exocrine by exogenous ghrelin administration in Sprague-Dawley rats. Journal of Animal Science and Technology 2014 56:6. 